SECTION 11. Biology. Ecology. Veterinary.

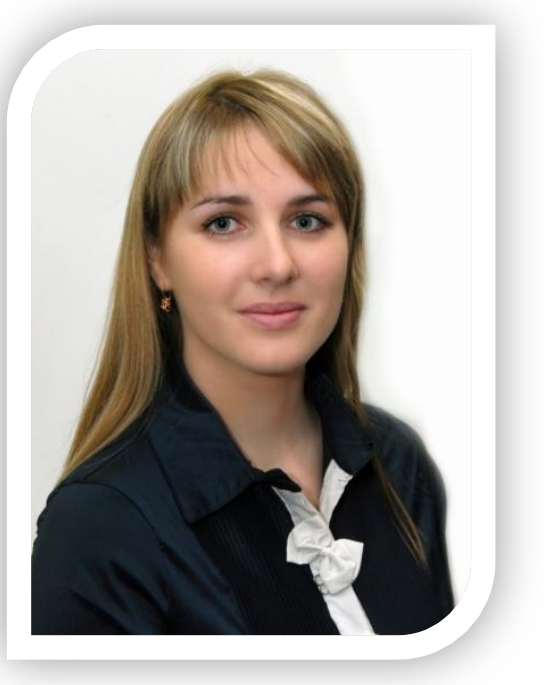

\author{
Momot Alena Andreyevna \\ Khakass state University named after \\ N.F. Katanov, \\ The Republic Of Khakassia, Russia
}

\title{
GEOBOTANICAL DESCRIPTIONS OF POPULATIONS WITH THE PARTICIPATION OF SANGUISORBA OFFICINALIS L.
}

The article examined the material when disturbed vegetation communities, as well as the anthropogenic load.

Keywords: geobotany, cenopopulation, plant resources.

\section{ГЕОБОТАНИЧЕСКИЕ ОПИСАНИЯ ЦЕНОПОПУЛЯЦИЙ С УЧАСТИЕМ SANGUISORBA OFFICINALIS L.}

В статье изучаются ценопопулящии при нарушенных растительных сообществах, а также при антропогенной нагрузке.

Ключевые слова: геоботаника, ценопопулячии, растительные pecypcbl.

Быстрое истощение растительных ресурсов, в связи с не рациональным использованием, а так же часто повторяющиеся неурожайные годы потребовали широко развернутых комплексных ботанических исследований $[1$, c. 5].

Sanguisorba officinalis L. (кровохлебка лекарственная) - травянистое короткокорневищное поликарпическое лекарственное растение. Стебель прямостоячий, большей частью одиночный, ребристый и полый внутри. Листья длинночерешковые, непарноперистые, зубчатые. Цветки правильной формы, мелкие, буро - красные, четырехчленные [2, с. 201].

S. officinalis обладает лекарственными свойствами, широко применяется в медицине и ветеринарии. Из корней и корневищ делают галеновые формы лекарств, которые используют в качестве вяжущих, кровоостанавливающих и противомикробных средств [3, с. 101]. 
Исследования проводились на территории Минусинской котловины, в вегетационный период 2010 - 2012 года.

Геоботанические описания ценопопуляций (ЦП) проводили по общепринятой методике [5, с. 114]. Выявлен видовой состав, общее проективное покрытие травостого (ОПП), проективное покрытие вида (ППВ) $[4$, с. 36]. Исследовали тринадцать ценопопуляций описанных в разных растительных сообществах: одна - степная (ЦП 1), четыре луговых (ЦП 2 - 5), одна - залежь (ЦП 6) и семь - лесных (ЦП 7 - 13).

Проективное покрытие вида во всех исследуемых растительных сообществах варьирует от 1 до $9 \%$. В степных растительных сообществах S. officinalis встречается единично. Общее проективное покрытие в различных растительных сообществах колеблется от $55 \%$ до $95 \%$. Наименьшее ОПП составляет в степи и на залежи, на луговых и в лесных ценозах ОПП варьирует от 70 до $95 \%$.

В настоящей степи (ЦП 1) общее проективное покрытие составляет 55 - $60 \%$, сухостой занимает $25-30 \%$, на открытые участки почвы приходится $5 \%$. Кустарниковый ярус отсутствует. В травяном ярусе доминируют злаки и осоки: Poa sibirica Roshev. - 5 \%, Alopecurus arundinaceus (Willd). Link. - $3 \%$, Elytrigia repens (L). Nevski - $3 \%$. Разнотравье в этих фитоценозах представлено: Artemisia tanacetifolia L. - 3 $\%$, Galium bariale L. $-2 \%$, Veronica incana L. $-1 \%$.

В луговых растительных сообществах (ЦП 2 - 5) ППВ варьирует 1 $4 \%$, ОПП от 75 до $95 \%$. В кустарниковом ярусе встречаются следующие виды растений: Spiraea flexuosa Fisch. ex. Cambess. - 3 - $5 \%$, Caragana pygmaea (L.) DC. - $3 \%$, Cotoneaster melanocarpus Lodd. - $1 \%$. Spiraea flexuosa и Caragana pygmaea имеет проективное покрытие почти в 2 раза больше, чем Cotoneaster melanocarpus. Единично в отдельных растительных сообществах встречается Spiraea media Franz. Schmidt. В трявяном ярусе сухостой составил $3-5 \%$. На лугах доминирует разнотравие: Elytrigia loliodes (Kar. et Kir.) Nevski $5 \%$, Onobrychis arenaria (Kit.) DC. - $4 \%$, Veronica incana L. $3 \%$, Achillea millefolium L $2 \%$, Aster sibiricus L. $-2 \%$, Elytrigia repens (L.) Nevski - $2 \%$.

На кустистарниковой злаково - разнотравной залежи (ЦП 6) верхний ярус занимает $10 \%$, представлен единичными видами Caragana arborescens Lam., Padus avium Mill., Sorbus sibirica Hedl. В кустарниковом ярусе доминирует Spiraea flexuosa Fisch. ex. Cambess. с проективным покрытием $7 \%$. Общее проективное покрытие травяного яруса составляет $70 \%$, сухостой $10 \%$, почва - $3 \%$. Доминанты: Poa repens (L.) Nevski. - 9 $\%$, Polygonum alpinum L. - $5 \%$, Lamium album L. - 3 \%. Залежь, как и все исследуемые растительные сообщества, является характерным местом произростания S. officinalis и распологается между двух возвышенностей за счет чего там скапливаются осадки. При описании этого растительного сообщества обнаружен Hedysarum minussinense B. Fedtsch. (сем. Fabaceae 
Lindl.), занесенный в Красную Книгу Республики Хакассия (2002; 2012) со статусом 3 - редкий вид, эндемик хакасско - минусинских степей. Реликт плиоценового возраста.

В исследуемых лесных растительных сообществах (ЦП 7 - 13) верхний ярус представлен Betula pendula Roth. и Pinus sylvestris L. Доминирующими видами в кустарниковом ярусе являются Rosa acicularis Lindl., Picea obovata Ledeb., Betula humilis Schrank. В травяном ярусе доминируют Elytrigia repens (L.) Nevski., Scirpus sylvaticus L., Pteridium aquilinum (L.) Kuhn ex Decken., Equisetum arvense L., Eq. hyemale L., Eq. sylvaticum L., Geranium pratense L., Alchemilla vulgaris L., Fragaria vesca L., Pyrola incarnate (DC.) Freyn. Общее проективное покрытие мохового покрова в березовом лесу составляет $15-20 \%$, в данном растительном сообществе, так же как на залежи высокое увлажнение. Общее проективное покрытие исследуемых сообществ в среднем составляет $75-85 \%$, проективное покрытие S. officinalis от 1 до $9 \%$.

Таким образом, было выявлено, что все ЦП исследуемого вида встречаются в степи, залежи, настоящих лугах, березовом, сосновом и смешанном лесу. Среди всех изученных ценопопуляций десять ЦП произрастают в ненарушенных растительных сообществах (ЦП $1-3$, ЦП 6 - 8, ЦП 10 - 13). Остальные три ценопопуляции (ЦП 4 - 5, ЦП 9) в нарушенных растительных сообществах, так как в луговых растительных сообществах (ЦП 4 - 5) наблюдалась антропогенная нагрузка в виде выпаса скота, а в березовом лесу (ЦП 9) производился сенокос.

\section{Литература}

1. Воронов А.Г. Геоботаника: учебное пособие. М.: Высшая школа, $1963.374 \mathrm{c}$.

2. Казарина Т. Растения - целители. Смоленск: Русич, 1996. 604 с.

3. Минаева В.Г. Лекарственные растения Сибири. Новосибирск: Наука, $1991.428 \mathrm{c}$.

4. Раменский Л.Г. Избранные работы (проблемы и методы изучения растительного покрова). Ленинград: Наука Ленинградское отделение, $1971,334 \mathrm{c}$.

5. Ярошенко П.Д. Геоботаника. М.: Просвещение, 1969. 200с. 